\title{
A legend in thoracic surgery: F. Griffith Pearson, MD, 1926-2016
}

\author{
Shaf Keshavjee, MD
}

\footnotetext{
From the Division of Thoracic Surgery, Toronto General Hospital, University Health Network, Toronto, Ontario, Canada.

Disclosures: Author has nothing to disclose with regard to commercial support.

Received for publication Oct 26, 2016; accepted for publication Oct 26, 2016; available ahead of print Nov 30, 2016.

Address for reprints: Shaf Keshavjee, MD, Division of Thoracic Surgery, Toronto General Hospital, 190 Elizabeth 8 St, RFE 1-408, Toronto, Ontario M5G 2C4, Canada (E-mail: Shaf.Keshavjee@uhn.ca).

J Thorac Cardiovasc Surg 2017;153:228-9

$0022-5223 / \$ 36.00$

Copyright (c) 2016 by The American Association for Thoracic Surgery

http://dx.doi.org/10.1016/j.jtcvs.2016.10.056
}

Dr F. Griffith "Griff" Pearson, a legendary leader in thoracic surgery, was born in Toronto, Canada, on July 7, 1926, and died peacefully on August 10, 2016. He attended University of Toronto Schools and then completed undergraduate studies followed by medical school at the University of Toronto, graduating as a silver medalist in 1949. After an internship at the Toronto General Hospital, he went into general practice for 1 year in Port Colborne, Ontario. He returned to the University of Toronto for 1 year of research studies under Dr Wilfred G. Bigelow and subsequently entered general practice in Wawa, in northern Ontario, for the next 3 years. In 1955, Dr Pearson returned to the University of Toronto to complete a residency in general surgery. He developed an interest in surgery of the chest, which was just developing at the time, and became passionately focused on the management of thoracic diseases. As a McLaughlin Travelling Fellow, he trained under Ronald Belsey in Bristol, England, and subsequently returned to a faculty position at Toronto General Hospital, where he ultimately spent his entire career.

In 1968, under Griff's leadership, a separate Division of Thoracic Surgery was established in the Department of Surgery at the University of Toronto. This ultimately led to the establishment of a separate specialty by the Royal College of Surgeons of Canada. Dr Pearson is widely recognized throughout the world as the founder of the specialty of thoracic surgery and for the establishment of the "Toronto School of Thoracic Surgery" at Toronto General Hospital, University of Toronto. This training program became the template for thoracic training programs throughout the world. In fact, the majority of graduates of the "Toronto Program" are now preeminent international leaders in the field of thoracic surgery, heading their own programs around the globe.

Dr Griff Pearson was an innovative thinker who instilled in all his students the belief that hard work, a scientific approach, and perseverance can solve the toughest challenges in medicine, as proven by his life and work. Griff introduced mediastinoscopy to the management of lung

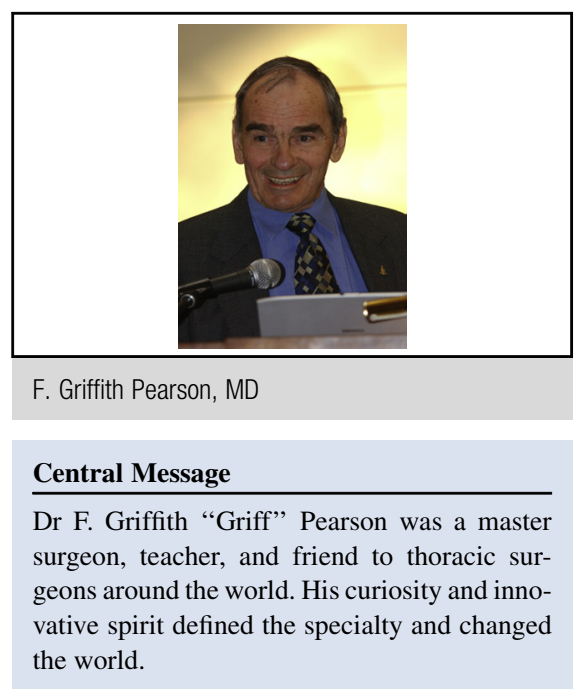

cancer staging, developed the first intensive care unit in Canada, and performed key experimental studies in tracheal surgery, enabling the development of advanced tracheal resection for benign and malignant disease. He developed innovative procedures that came to bear his name in tracheal surgery (the Pearson Operation for crico-tracheal resection and reconstruction) and in esophageal reflux surgery (the Collis-Belsey operation). His pioneering leadership and early research on airway surgery set the stage for the team that he assembled in Toronto to ultimately achieve the first successful lung transplant in the world.

Above all, Griff was a wonderful teacher with a unique clarity of thought and speech and an outstanding ability to convey his message clearly. Griff had a natural curiosity and willingness to learn new things that were infectious. He was generous with his time and gave it enthusiastically to his students, who came from all over the world to learn from this master surgeon. A true gentleman, he treated all of his students and colleagues with great respect and always remembered names, making each person feel important. Every surgeon who trained with Griff would one day ask, when faced with a difficult situation, "What would Griff do here?" to find the answer. Each will fondly remember his famous invocations: "Jeeesus Christ!" and "Lord love a duck!" at critical moments in Griff's operating room.

Griff loved to spend time at his cabin near Mansfield, Ontario, north of Toronto. He enjoyed the outdoors, marveled at nature, and was an avid fisherman. He enjoyed time with his family tremendously and with his "second family"- 
his residents and thoracic surgeon colleagues. He is responsible for building the careers of many of the world's leading thoracic surgeons.

Griff Pearson has 3 children from his first marriage to Eva Pearson: Niels, Liz, and Jenny Pearson. He remarried and spent the second half of his life with Hilppa Pearson, who has a daughter from her first marriage, Nina Schafrick. Hilppa and all the children were at his side until the end.

Dr Griff Pearson was Surgeon in Chief of Toronto General Hospital from 1978 to 1989 . He was elected as the 70th president of The American Association for Thoracic
Surgery from 1989 to 1990 . He also received the Lifetime Achievement Award from The American Association for Thoracic Surgery in 2004. In 2002, he was appointed as a Member of the Order of Canada, the country's highest civilian honor, for his contributions to thoracic surgery in Canada and around the world.

Griff was a brave master surgeon, teacher, and friend to many. He positively touched the lives of all those he encountered, truly defining the specialty and changing the world. His talent, wonderful bedside manner, innate curiosity, and innovative spirit were an inspiration to us all.

Access to The Journal of Thoracic and Cardiovascular Surgery Online is reserved for print subscribers!

Full-text access to The Journal of Thoracic and Cardiovascular Surgery Online is available for all print subscribers. To activate your individual online subscription, please visit The Journal of Thoracic and Cardiovascular Surgery Online, point your browser to http://www.mosby.com/jtcvs, follow the prompts to activate your online access, and follow the instructions. To activate your account, you will need your subscriber account number, which you can find on your mailing label (note: the number of digits in your subscriber account number varies from 6 to 10 ). See the example below in which the subscriber account number has been circled:

\section{Sample mailing label}

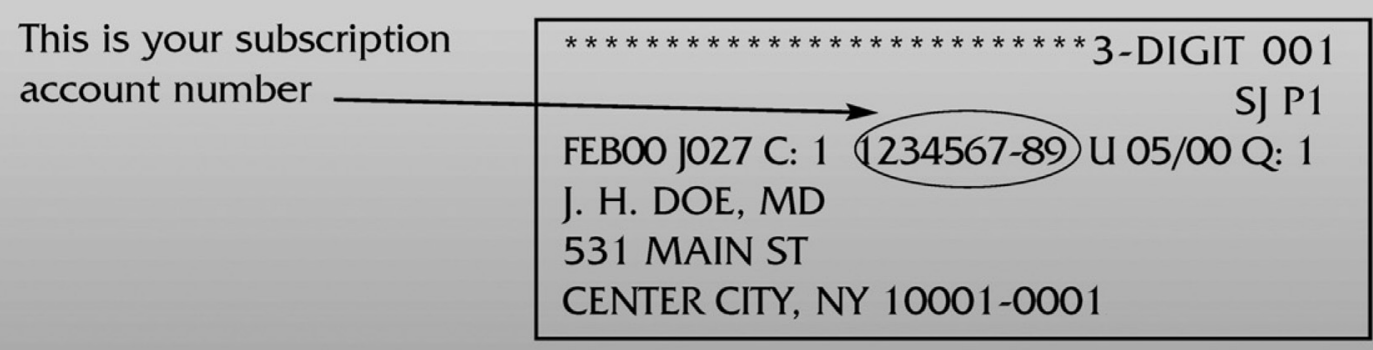

Personal subscriptions to The Journal of Thoracic and Cardiovascular Surgery Online are for individual use only and may not be transferred. Use of The Journal of Thoracic and Cardiovascular Surgery Online is subject to agreement to the terms and conditions as indicated online. 